\title{
河川事業における住民と行政との 合意形成に関する実証研究 EXPERIMENTAL STUDY OF CONSENSUSBUILDING AMONG RESIDENTS AND ADMINISTRATORS ON RIVER PLANNING
}

\author{
河田 恵昭 $^{1} \cdot$ 上田 征香 $^{2} \cdot$ 川方 裕則 $^{3} \cdot$ 後藤 隆一 $^{4}$ \\ Yoshiaki KAWATA, Yuka UEDA, Hironori KAWAKATA Ryuichi Goto \\ 1フェロー 工博 京都大学防災研究所 教授 (T611-0011 京都府宇治市五ヶ生) \\ ${ }^{2}$ 正 会 員 修士（情報） アジア航測株式会社（テ462-0823 愛知県名古屋市北区東大曽根町上 5-1071） \\ ${ }^{3}$ 非 会 員 博士 (理学) 京都大学防災研究所 助手 (T611-0011 京都府宇治市五ヶ庄) \\ 4 学生会員 修士（工学） 京都大学情報学研究科 博士課程（テ611-0011 京都府宇治市五ヶ庄）
}

\begin{abstract}
The framework of decision-making process and the way to make a consensus among residents and river administrators are pursued. Interviews were held to river administrators and representatives of NPOs that typical three cases of river planning concern. The results of this research revealed three points to improvement the ongoing river administrative. The first is changing framework of river administrative that doesnit allow public involvement in flood control. The second is NPOs' working with river administrators for educational activities. The third is NPOs continual acts in neutral position.
\end{abstract}

Key Words : consensus-building, public involvement, decisionmaking process, acceptable risk, selfresponsibility

\section{1. 緒言}

最近，公共事業を実施する際に社会的合意が必要 条件となってきている. 河川行政においても，平成 9 (1997) 年の河川法改正で, 河川整備計画の策定に 住民の意見を反映することが新たに認められた。そ こで，各河川では，住民の意見を集約し代弁する NPO 法人や住民団体が発足してきている。一方，防 災分野においては，河田 ${ }^{1)}$ が，住民の自己責任原則 や受容リスクといった考え方の導入が必要であり， この実現にあたっては社会的合意が不可欠であると 指摘している．ここで，住民の自己責任原則とは， 「自分の生命と財産は自分で守る」というものであ り，受容リスクとは，「倫理的に政府が責任を負わ なくてはならない『社会的に受け入れられる危険の 限度』」と定義されている ${ }^{2)}$. すなわち，「政府が 担保した計画以上の外力に対して，住民は被害の発 生を甘受し，被害軽减の対策を講じなければならな い」という考え方である. しかし，合意形成に向け た住民参加の取組は最近開始されたばかりであり， ノウハウが十分に蓄積されているとは言い難い。
そこで，本研究では，治水対策をはじめとした河 川行政におけるあるべき意思決定過程の枠組みを追 求する. 合意形成には, 住民と行政, 住民間等様々 な主体間での問題が考えられる.しかし，これらの 問題を一度に扱うことは困難である.したがって, 本研究では, 頻繁に注目されている住民と行政との 合意形成について検討を行ったそそのために合意形 成のモデルケースとして紹介されている多摩川水系 河川整備計画, 多摩门とは対照的な非都市の特徵を 有する由良川水系河川整備計画，および我が国で最 も対立の激しい事例の 1 つである吉野川第十堰改筑 計画の 3 つを対象とし, 聞き取り調査を実施した。

\section{2. 対象とした計画の策定過程と住民参加}

\section{(1)多摩川水系河川整備計画}

図-1 は, 多摩川水系河川整備計画策定過程のフロ 一を示したものである.計画策定の各段階において， 河川管理者や住民団体等が様々な取組を実施してお り，それぞれの結果がフィードバックされている. また最終決定は河川管理者が行う構造になっている. 


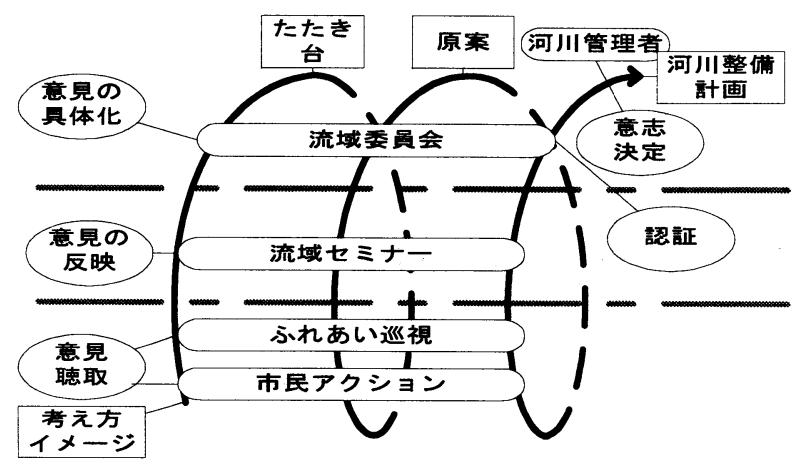

図- 1 多摩川水系河川整備計画策定計画

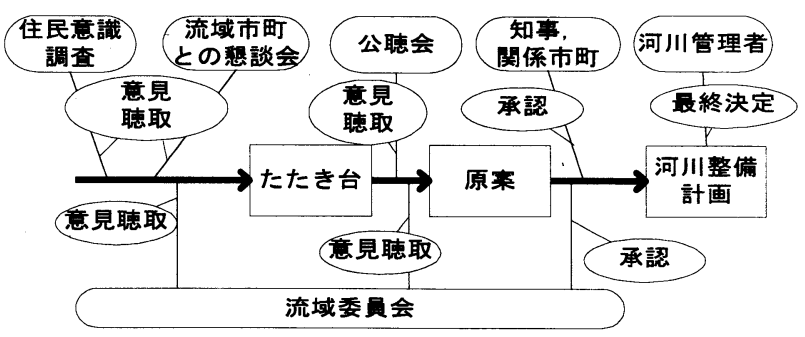

図-2 由良川水系河川整備計画策定過程

\section{（2）由良川水系河川整備計画}

図-2 は由良川水系河川整備計画策定過程のイメ ージを示したものである. 由良川水系河川整備計画 策定では河川管理者が各段階で取組を行っており， 最終決定は河川管理者が行う構造になっている.

\section{(3)吉野川第十堰改築計画}

表-1 は, 吉野川第十堰の計画策定から白紙撤回に 至るまでの主な動きを年表に示したものである。こ こでは, 計画の策定段階において住民参加の機会が ほとんどなかったことが特徵である.計画策定後は， 反対運動が活発化してから開始された広報活動があ る. また，住民投票実施と前後して，改築計画に理 解を求める活動から，吉野川全体に対して情報を提 供する活動へ移行している．これは，この頃，河川 行政の過渡期にあたり, 河川整備計画の策定も視野 に入ってきたことが背景にある。

\section{3. 調査概要}

河川法上，河川整備計画に対する責任の所在は、 河川管理者にあるとされているが，今日では住民参 加で住民の意見が反映されるようになってきている。 このような状況で計画に対して河川管理者のみが責 任を負うことに何の問題もないのであろうか. そこ で本研究では，対象とした河川において計画に対す る責任の所在の現状と当事者らが考える理想を調査 することを第 1 の目的とした. また，これらの計画 について，合意が困難になる原因の実態調査を第 2
表-1 吉野川第十堰改築計画を巡る動き

\begin{tabular}{|c|c|c|}
\hline 年 & 改築計画を巡る動き & 住民参加の取組 \\
\hline 1966 & 徳島県が国に第十堰改修の要望 & \\
\hline 1982 & $\begin{array}{l}\text { 建設省が吉野川工事実施基本計画 } \\
\text { に既設の固定堰改築の必要性を初 } \\
\text { めて明記 }\end{array}$ & \\
\hline 1991 & $\begin{array}{l}\text { 特定多目的ダム法に基づき改築計 } \\
\text { 画が策定 }\end{array}$ & \\
\hline$\overline{1992}$ & 環境調查委員会設置 & \\
\hline 1993頃 & $\mid$ 反対運動開始 & \\
\hline 1995 & 建設事業審議委員会設置 & \\
\hline \multirow{2}{*}{1998} & 反対運動活発化 & $\begin{array}{l}\text { パネル展, パンフレット等 } \\
\text { の広報活動 }\end{array}$ \\
\hline & $\begin{array}{l}\text { 審議委員会が「可動堰化計画は妥 } \\
\text { 当」との }\end{array}$ & \\
\hline \multirow[t]{2}{*}{1999} & $\begin{array}{l}\text { 徳島市における住民投票で過半数 } \\
\text { の反対 }\end{array}$ & $\begin{array}{l}\text { 地区別説明会, 対話集会開 } \\
\text { 始 }\end{array}$ \\
\hline & $\begin{array}{l}\text { 「明日の吉野川と市民参加のあり } \\
\text { 方を考える㤠談会」の設置を決定 }\end{array}$ & ツア一等の開始 \\
\hline \multirow[t]{2}{*}{2000} & $\begin{array}{l}\text { 「明日の吉野川と市民参加のあり } \\
\text { 方を考える愁談会」設置 }\end{array}$ & \\
\hline & 白紙撤回 & \\
\hline 2001 & 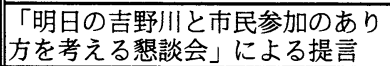 & \\
\hline
\end{tabular}

の目的とした．加えて，合意形成を困難にしている 一因として考えられる知識に関しても調査を行った。 各調査の詳細は後述する.

調査の対象は，国土交通省の各事務所の住民参加 担当者と住民参加に携わった NPO とした。具体的 には，多摩川は京浜工事事務所と NPO 法人多摩川 センター（以下, 多摩川 NPO), 由良川は福知山工 事事務所と NPO 法人由良川流域ネットワーク（以 下, 由良川 NPO）, 吉野川は徳島工事事務所と NPO 法人吉野川みんなの会 (以下, 吉野川 NPO) とした. 各 NPO の設立目的は異なるが，NPO は，NPO 法に より非営利の公益性を備えている団体として認可を 受けていることから, 本研究では，一様でない住民 意見を総括する団体として位置づけた。

\section{(1)責任の所在}

ここでは，それぞれの計画に対する責任の所在の 現状と理想を明らかにすることを目的とした。その ため Arnstein $^{3)}$ の住民参加のはしご」を河川事業に 適用することを試みた。表-2 は，「住民参加のはし ご」を河川事業に適用して，「権利者」を「河川管 理者」に，「権利のない者」を「住民」として定義 しなおしたものである。

\section{(2)計画策定過程}

ここでは，計画策定過程に対する不満の有無を明 らかにしようとした. 計画策定過程に対して不満を 持つ原因として, 取組が十分でないことと, 取組が 十分であってもそれが住民に伝わっていないことが 考えられる．そのために，取組が十分でないことに 対しては，「住民参加のはしご」を用いて理想と現 状の相違や河川管理者が取組を実際より高い段階と 評価する過大評価の有無で判断し，取組が住民に伝 
わっていないことに対しては NPO の代表が過小評 価していないかどうかで判断した。

\section{(3)知識}

住民の知識が十分であるかを直接調査すること は困難であるため, 河川管理者と NPO がそれぞれ に行っている啓発活動と知識供給活動について実態 を調査し, これらの内容から知識の偏りについて検 討を行った。 また，知識不足が原因で合意形成が円 滑に進まなかった例の有無も確認した.

\section{4. 調査結果}

調查の結果, 調査の目的であった 2 点と, 新たに NPO のコーディネーターとしての役割や NPO の抱 える問題点も明らかになった.

\section{(1) 定任の所在}

図-3 は, 各計画策定の際に実施された住民参加の 取組を住民参加のはしごを用いて評価させた結果で ある.なお，線グラフで示した「定義による評価」 とは表-2 に従って筆者らがヒアリングの中で得ら れた意思決定者意見取り入れの有無等に関する発 言より評価した結果である. また，吉野川の全体評 価は懇談会前と懇談会後の 2 つに分けた.

これによると，河川管理者は全員現状と理想を 5 段目と評価している。これについて，河川管理者は 全員「住民に責任を持たせることが困難なため，5 段目より上に上げるべきではない」，したがって「河 川管理者が責任を取らなくてはならない」との考え を示している. 一方， NPO は現状を 5 段目以下と 評価し,理想を 6 段目以上と評価している.しかし， 責任の所在について, 多摩川 NPO は，「住民が責 任を持つべきかどうかわからない」と述べている. また, 由良川 NPO は, 「住民が責任を持つのは難 しい」との考えを示している。これに対して，吉野 川 NPO は，「流域自決」という言葉を用いて，自 分たちで責任を持って意思決定したいと述べた。ま た, 理想の段階に上げるために必要なこととして, 共通して述べられていたことは，住民が河川に対し て興味や関心を持つことであった。

\section{(2) 計画策定過程}

まず，理想と現状との相違について述べる．図-3 によると, 3 河川の河川管理者が答えた理想と現状 には相違がみられない。また，河川管理者の過大評 価もみられなかった。一方, NPO が答えた理想と現 状には相違がみられる。しかし, 多摩川 NPO と由 良川 NPO は「情報が良く出ている」という点を評 価しており，「河川管理者は変なことができないだ
表-2 河川事業における住民参加のはしごの定義

\begin{tabular}{|c|c|c|}
\hline 分類 & 鼄階 & 説明 \\
\hline \multirow{3}{*}{ 市民権力 } & 8 & 口住民が十分な意志決定の管理権を持つ \\
\hline & 7 & —住民が意志決定の多くの議席を持つ \\
\hline & 6 & $\begin{array}{l}\text { 口河川管理者と住民の立場が対等 } \\
\text { 口住民は意思決定の責任を持つ }\end{array}$ \\
\hline \multirow{3}{*}{$\begin{array}{l}\text { 形式だけ } \\
\text { の参加 }\end{array}$} & 5 & $\begin{array}{l}\text { 口原則的に住民の代表者に助言の権利が } \\
\text { 与えられている } \\
\text { 口最終決定権は河川管理者が持つ } \\
\square \text { 住民の代表者には意志決定の責任がな } \\
\text { ○委員会等 }\end{array}$ \\
\hline & 4 & $\begin{array}{l}\text { 口住民は情報を得て, 意見を述べること } \\
\text { ができる } \\
\text { 口河川管理者がその意見を取り入れる保 } \\
\text { 証はない } \\
\text { ○意識調査, 地域会議, および公開ヒア } \\
\text { リング等 }\end{array}$ \\
\hline & 3 & $\begin{array}{l}\text { 口住民は情報を得ることができるが, 意 } \\
\text { 見を述べることはできないく一方通行の } \\
\text { 情報> } \\
\text { ○パンフレット, ポスター, 問い合わせ } \\
\text { に対する回答, および説明会等 }\end{array}$ \\
\hline \multirow{2}{*}{ 不参加 } & 2 & \multirow{2}{*}{$\begin{array}{l}\square \text { 河川管理者が住民を教育したり, 矯正 } \\
\text { したりする } \\
\text { 口住民が計画策定に参加することはでき } \\
\text { ない } \\
\text { く単純な情報提供ではなく，意図的な情 } \\
\text { 報操作によって理解を求める，> } \\
\text { ○広報活動や説明等 }\end{array}$} \\
\hline & 1 & \\
\hline
\end{tabular}

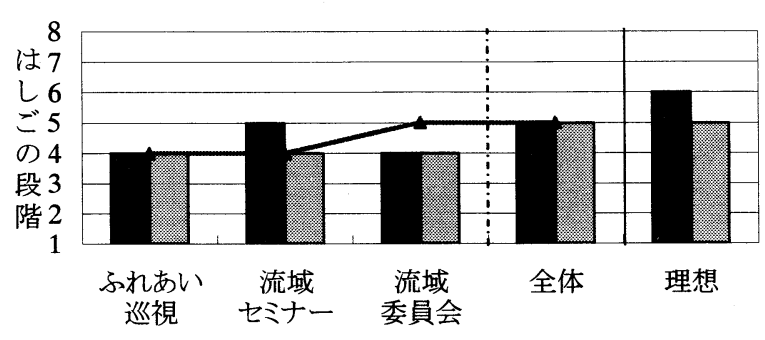

(1)多摩川

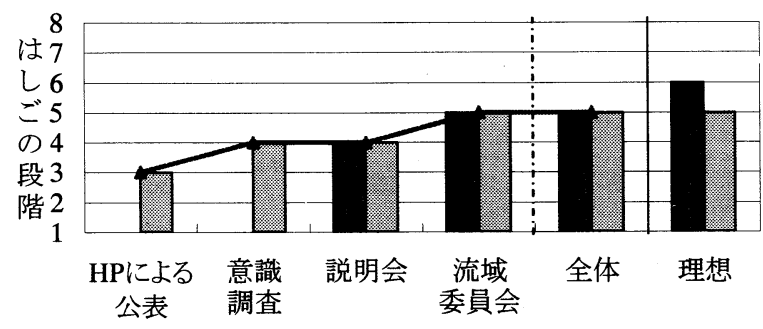

(2)由良川

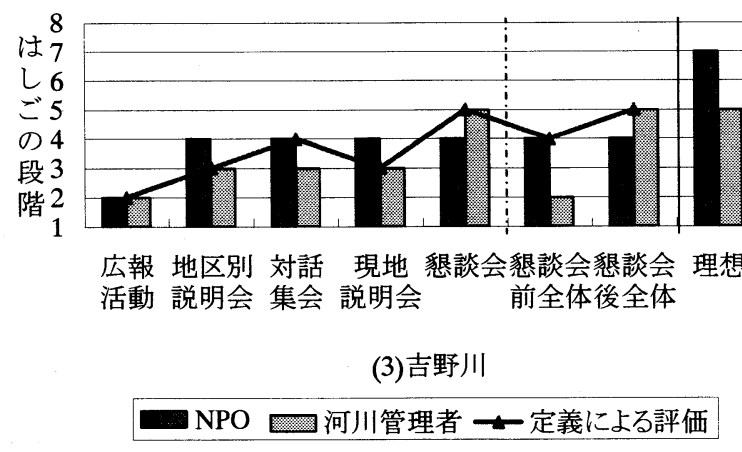

図-3 住民参加のはしごを用いた評価 
ろう」と述べている．これに対して，吉野川 NPO は「河川管理者は流域住民が川づくりを行う上での サポート役をするのが理想」と述べた. 図-3 から吉 野川では他の河川と比較して, 取組が十分でなかっ たことがわかるが, 理想と現状の差からも NPO が 現状の取組が十分ではないと考えていることがわか る.

次に, NPO の代表が各取組に対して行った評価が 過小でないかどうかについて述べる.ここでも，多 摩川と由良川では破綻を来すような過小評価はみら れなかった.しかし，吉野川では，懇談会後の取組 に関して NPO の代表が河川管理者や定義による評 価よりも低い段階を示している。このことから，河 川管理者の意図が十分通じていないことがわかる. このように答えた理由として, 吉野川 NPO は,「出 していい情報と出したくない情報を分けているとい まだに感じる」とも述べており，いまだに不信感が 消えない様子を語っている。

\section{(3)知識}

ここでは, 特徵としてみられた点について簡単に 述べる．まず，啓発活動に共通してみられた点は，

「子どもへの啓発」である.この理由として, 由良 川と吉野川の NPO が子どもは惹きつけやすいこと, 子どもから家庭へ伝わる流れが期待できることを挙 げている. 次に共通してみられた点は, 多くの主体 が「一般の住民にはまず関心を持ってもらうことが 必要」と述べ, 啓発活動の重要性を指摘したことで ある。これについて多摩川の河川管理者や由良川 NPO は住民が啓発活動で関心を持つようになれば, 自主的に知識や情報を得るようになると期待してい る.一方, 知識供給活動については, 河川管理者は 比較的多くの活動を行っているが, 多摩川と由良川 NPO については, 知識供給活動が少ない。ただし, 対内的な勉強会等は活発に行っているようである. 吉野川 NPO は, 一般に向けた知識供給に加えて体 内的には，専門的な知識も勉強している点が特徵的 である。 NPO 自身の知識の入手方法としては, 河 川管理者からの情報や独自の勉強の他に, 大学によ る協力が挙げられており, 大学の役割も明らかにな った。

次に，知識不足がネックになったことがあったか どうかについて述べる. まず, 多摩川の場合, 河川 管理者は「環境に対しては相当な知識を持っている が，治水についてはあまり議論にならなかった」と 述べ, 重ねて「治水のことは河川管理者に任せても らっている.そのためか治水についてはあまり議論 にならなかった。言い換えると関心がないのではな いか」との懸念を示した. 次に, 由良川の場合, 河
川管理者は「過去の経験や『ここまで水が来ました』 と書いてあるプレート等から, 1953 年規模の洪水と 言えばわかってもらえる」，「治水に対しては認識 が高い」等を理由に知識不足がネックになるような ことはなかったと述べている．また，住民からの指 摘で治水の項目に修正を入れたというようなエピソ 一ドについても触れ, 由良川では知識不足がネック になることはないと指摘した.すなわち頻発する河 川氾濫自体が知識供給の代役を果たしていると考え られている，なお，吉野川は今回検討を行えなかっ た.

\section{（4）コーティネーター}

多摩川センターの活動目的をみると NPO が「コ 一ディネーター」としての役割も果たし得ることが わかる。多摩川センターは, 多摩川流域内外におい て様々な主体のパイプ役として機能を果たすことを 目的として活動を行っているが，特に，流域内で河 川管理者と住民とのコーディネート役として重要な 役割を果たしてきた。これについては, 河川管理者 が「多摩川センターの存在が大きかった」と評価し ている点からも明らかである.

\section{5. 合意形成が困難になる原因}

\section{（1）信頼と計画策定過程}

多摩川 NPO と由良川 NPO の意見として, 理想と 現状に相違がみられたものの，責任を取ることが難 しいこと，および「河川管理者は変なことができな いだろう」という考えから計画策定過程に対して不 満はみられなかった。一方, 吉野川ではいまだに不 信感がみられ，河川管理者の取組意図が NPO に伝 わっていなかった。そこで，キーワードとなるのは 「信頼」である。ここで山岸 ${ }^{4)}$ の信頼」の定義を 用いると, 多摩川や由良川では, 住民参加の取組の ために少なくとも「安心」があるものと考えられる. 一方, 吉野川では, NPO の代表が河川管理者に対し て現在でも「安心」していないことがわかる.

\section{(2)合意形成と知識}

河川管理者や NPO は知識の必要性を認識し, そ れぞれに啓発活動や知識供給活動を行っている。し かし, NPO の活動については, 知識供給活動があま り行われておらず，住民がバランス良く知識を得て いるか疑問である. 特に，多摩川の河川管理者は住 民の環境への関心の偏りに対して眯念を示している. これに対して, 由良川では, 河川管理者が住民の治 水に対する関心が高く, 過去の水害がどの程度かを 経験的に理解できる点を指摘していた.したがって, 計画高水流量が十分かといった議論が可能である. 
一方, 吉野川では, 河川管理者, NPO ともそれぞれ に知識供給に熱心に取り組んでいた。このように， 由良川と吉野川では，住民の知識に偏りがないとは 言い切れないが，それぞれに知識の土壌があること がわかった.

\section{6. 河川事業の合意形成に関する考察と提案}

\section{(1)自己责任と河川法の限界}

現在防災分野で提唱されている，受容リスクや住 民の自己責任原則の考え方と現行の河川法には矛盾 がある．まず，計画高水流量の決定の問題である. 計画高水流量とは, 河川整備基本方針によって定め られるものであり,これについて住民参加が認めら れていない。すなわち計画高水流量には，社会的合 意がなく、「受容リスク」の要件を満たしていない. にもかかわらず，それ以上の外力に対して住民はそ の発生を甘受しなくてはならない，また，環境の問 題と治水の問題が対峙した吉野川第十堰の場合, 住 民意見を尊重して白紙撤回された。しかし，現行制 度では，これに対しても河川管理者が全ての責任を 負わなくてはならず，自ら甘受したリスクについて 責任を持つという自己責任原則との間に矛盾が生じ ている. 加えて, 多摩川の河川管理者が「治水のこ とは河川管理者に任せてもらっている．言い換える と関心がないのではないか」と述べたことからもわ かるように，河川管理者が責任を持って最終意思決 定を行うことが，住民の河川管理者に対する過度の 依存や治水への無関心につながっている．高橋 ${ }^{5)}$ は このような状態を「治水施設を建設し管理している 人々に, 治水の全責任があると考えるのは無理であ る一方，いわゆる治水当局が無限の責任意識を持つ ことは，不遜でさえある」と批判している。

このように, 河川法上認められている住民参加の 限界と受容リスク，および自己責任のあり方との関 係にある矛盾を解消するために, 河川整備基本方針 を含む「全ての」意思決定過程において，少なくと も「6 段目以上」の住民参加を実施する必要がある と考えられる。

\section{(2)信頼の崩俵と現状の打破}

多摩川と由良川 NPO は, 河川管理者への安心か ら, 現状の意思決定過程に不満はないようである. そこで,これらの河川と同様の過程を踏めば, 計画 策定過程が原因で強硬な反対を受けるようなことは 起こりにくいと考えられる. しかし, すでに信頼が 崩壊している吉野川では，多摩川や由良川と同様の 取組を行才うとしているが，いまだに不信感が消え ず，NPO に河川管理者の意図が伝わっていない。し たがって，信頼が崩壊している状態では，5段目の
取組をいくつ行っても合意形成には至らない。そこ で, 本研究では, すでに信頼が崩壊してしまった事 例においても，意思決定が行える枠組みについて検 討したい. 5 段目の住民参加の取組では不足してい ることはすでに指摘した。では，6段目以上ではよ゙ うであろうか. 6 段目は河川管理者と住民が対等で あり,お互いの意見を相殺し合うことも可能である. また， 7 段目や 8 段目では，さらに住民が持つ決定 権が大きくなる．このような場合，基本的にお互い を信用していなくても，対立や協働しながら議論す ることで，より良い結果を導くための努力が可能と なる.このような理由からも, 本研究では, 6 段目 以上の住民参加を含む意思決定の枠組みを提案した い.

\section{(3)合意形成と住民参加に対する提案}

以上のことから, 本研究では, 今後の河川行政に おける意思決定過程のあり方について, 以下の 3 点 について提言を行いたい．まず 1 点目に，住民参加 の段階について住民参加の段階を 6 段目以上に上げ ることである。これにより，住民が責任を持って意 思決定に参加することができ，非常時における自己 責任も果たしやすくなると同時に，吉野川のような 対立の激しい事例でネックになっている「信頼の朋 壊」がクリアできると考えられる. 2 点目に, 意思 決定の枠組みについて，水系一貫した河川管理が可 能な枠組みを維持すべきである.イギリスやフラン スなどの欧米諸国では，流域住民が河川管理を行っ ているが，水系一貫した河川管理が困難になってい る. 水系一貫した河川管理は優れた考え方であり， 今後も実施すべきである.そこで, 3 点目に NPO の あり方について提案する.水系一貫思想の実施には， 自分の住居の地先だけでなく，水系全体を見渡して 考える機関が必要となる．NPO は，その性質に公 益性を備えており，住民の視点から水系全体を見渡 して考えることが可能である. また，河川管理者と NPO がそれぞれの視点から, 流域全体を考えること によって，お互いをチェックし，対立もしくは協㗢 しながら意思決定を行うのが良いと考える.ここで， NPO のコーディネーターとしての役割が重要とな ってくる. 現在, 住民参加に携わっている NPO に は様々な団体がある. 各 NPO の住民参加に対する 姿勢はそれぞれ異なるが，今後，多摩川センターの ように流域全体の多様な意見を総括し，コーディネ 一ターとしての役割を担う中立的な立場を保つ NPO は重要となる.したがって, これらの NPO の 設立，育成，および活動支援は今後の課題となる. もちろ儿, NPO 側もコ一ディネータ一としての役割 を担えるように，その活動目的や組織構成について 充分検討する必要がある. また, NPO のもう 1 つの 
役割として, 啓発活動と知識供給活動の主体として の役割が挙げられる. 河川管理者だけでなく, NPO も啓発活動や知識供給を行うことには，住民の視点 から地域に密着した活動が行える点, 吉野川のよう に住民と河川管理者が対峙し不信感が生じているよ うな場合, 複数の情報源を確保することにより, 住 民がより中立的な立場から判断できるようになる点， および河川管理者と NPO の情報が相互にチェック 機能を果たし, 補完し合えるという点の 3 つがメリ ットとして挙げられる. 2 つ目と 3 つ目のメリット については，吉川 ${ }^{6}$ が「住民が信頼できる情報源を 選択してその情報を信じることが現実的である」と 指摘している. 確かに, 河川工学を含む治水に対し て一般の住民が意見を言うことは難しい。しかし， 由良川や吉野川の例にもあるように，一概に，「治 水のことを一般の人が理解し得ない」とするのは間 違いである. また，住民参加によって住民の治水に 対する関心を高め，知識を供給することで，「住民 も責任を持って計画策定に参加する」ことが可能に なると考えられる.そこで，NPOには専門知識をわ かりやすく伝える努力がより一層必要になる．この 点については, 専門家によるサポートも重要であり, 5 章で指摘した通り, 大学のスタッフなどが NPO の 活動に協力していく仕組みを作ることも大切である.

\section{(4)理想の実現に向けての課題}

以上に挙げた意思決定の枠組みを実施する際に， 障害になることとして, 現状の問題点を整理する. 本研究で実施した調查の結果, 明らかとなった問題 点は大きく 2 つに分けられる. 1 つは一般の住民の 関心の低さ，もう 1 つは現行体制の限界である. 2 つ目に挙げた現行体制の限界については，現行河川 法の限界, NPO の財政問題, および NPO あり方と 役割の 3 つの問題が挙げられる. 現行河川法の限界 として, 河川整備基本方針に対して住民の意見を反 映することができない点, および河川管理の責任を 河川管理者だけが負うように定められている点が挙 げられた。 この点については, 意思決定過程の枠組 みを変える必要があるだろう. 次に, NPO の財政問 題として, NPO の資金源と税制の 2 つの問題が挙げ られる.これらの問題は, NPO の活動の継続やコー ディネーターに求められる中立の立場を保持するこ とが困難になる結果をもたらしているＮNO は， 現在, 啓発活動や知識供給を行う主体のうちの 1 つ であると同時に, コーディネーターとしても重要な 役割を担っている. そこで，これらの役割を果たす NPO が中立の立場を保ちながら継続して活動を行 うために, 河川管理者ではない第三者からの安定し た活動資金源が必要となろう. 例えば，河川管理者 以外の機関からの収入源を確保する等の対策が考え
られる.このように第三者から活動資金を得ること によって，住民と住民の間，また河川管理者と住民 の間において中立的な立場を得ることができると考 えられるが,これについては,より詳しい検討が必 要となろう.

\section{7. 結語}

現状の河川行政を改善するために以下の 3 点が提 案される. 第 1 に, 治水に関して住民参加ができな いような現行の河川行政の枠組みを改めることであ る.これは住民の関心向上につながると考えられ， 相乗効果で住民が責任を持って判断することが可能 となるものと考えられる. 第 2 に, NPO や河川管理 者がそれぞれもしくは協働して, 啓発活動や知識供 給を行うことによって，住民が自ら責任を持って判 断し, 行動し得る状態に近づくと考えられる. 第 3 に, NPO が中立的な立場で, 継続的に活動できるよ う, 第三者からの安定した資金源の確保が必要とな ろう。なお, 本研究は, 住民と行政, 中でも河川管 理者との合意形成について検討を行ったものである. しかし, 本研究で対象としたこれ以外にも対立する 住民同士の合意形成等も重要な問題である.そこで, 今後, このような問題も踏まえた検討を行う必要が ある。

謝辞 : 今回, 聞き取り調查にご協力くださいました 皆様に感謝の意を表します．また，有益な助言をい ただいた京都大学防災研究所の井上和也教授, 林春 男教授に深く感謝いたします。

\section{参考文献}

1）河田恵昭 : 自然災害の変遷, 防㷋学ハンドブッ ク, 京都大学防災研究所編, 朝倉書店, pp.12-29 (2001).

2）日本災害学会 : 防災事典, 築地書館, pp.178-179 (2002).

3) Sherry Arnstein : A Ladder of Citizen Participation, AIP Journal, pp.216-224 (Jul.1969).

4）山岸俊男 : 信頼の構造ーこころと社会の進化ゲ 一ム, 東京大学出版会, pp.46-47 (1998).

5) 高橋裕: 国土の変貌と水害, 岩波新書 (1971).

6）吉川肇子: リスク・コミュニケーション, 福村 出版 (1999).

(2003.9.30受付) 